DOI: 10.20472/IAC.2019.045.024

\title{
SATISH KUMAR
}

Malaviya National Institute of Technology Jaipur, India

NISHA GOYAL

Jain Univeristy Bangluru, India

\section{EXPLORING BEHAVIOURAL BIASES AMONG INDIAN INVESTORS: A QUALITATIVE INQUIRY}

\begin{abstract}
:
Psychological factors influence individual investors' investment decision making, but few studies have used qualitative methods to understand these factors. The present study interviews experienced financial advisors and brokers working with individual investors. For the data analysis, a thematic content analysis approach with open coding was used. The findings of this study indicate that investors have numerous opinions and tendencies (categorized into cognitive errors, emotional biases and social interactions) that affect their investment decisions. This study suggests that an understanding of individual investors' behavioural biases can provide financial planners and advisers with additional knowledge to help their clients in making better financial decisions that potentially lead to improved investment results.
\end{abstract}

\section{Keywords:}

Psychological biases; investment decisions; individual investors; financial advisors; qualitative thematic content analysis

JEL Classification: G02, G10 


\section{Introduction}

In the stock market, individual investors exhibit different kinds of behaviour. Traditional finance theory (e.g., the arbitrage principles of Miller and Modigliani; the portfolio principles of Markowitz; the capital asset pricing theory of Sharpe, Lintner and Black; and the optionpricing theory of Black, Scholes and Merton) is based on the assumption that individual investors are capable of making fully rational financial decisions and are wealth maximizers. Efficient market theory, defined by Fama in 1970, states that in the efficient market, investors tend to act rationally, and stock prices incorporate and reflect all the available information. Moreover, expected utility theory argues that a decision maker analyses all the available alternatives based on their utility and associated risks and chooses the optimum decision. However, individual investors do not always make their decisions based only on certain reasons and logic; they are driven by emotions and psychological factors (Tourani-Rad and Kirkby, 2005).

Behavioural finance provides the explanation for this phenomenon. Although finance has been studied for thousands of years, behavioural finance is an emerging field that combines the behavioural or psychological aspects with conventional economic and financial theories to provide explanations on how emotions and cognitive factors influence investors' behaviours. These emotions and cognitive factors are known as behavioural biases. Because of these biases, investors make irrational investment decisions. Besides, the emotional and cognitive factors, the social influence of media as well as friends, relatives and colleagues also affect investment decisions (Baker and Nofsinger, 2002). In their seminal paper, two psychologists, Kahneman and Tversky (1979), have criticized the expected utility theory as a descriptive model of decision making under risk and have developed an alternative model of decision making, which is known as prospect theory. In the prospect theory, they advocate that people are loss averse and individuals dislike losses more than an equivalent gain. Hence, people are more willing to take risks, in order to avoid the losses. In another important study, Tversky and Kahneman (1981) presented the framing effect. They documented that if two problems are effectively identical but the only difference between them is that the outcomes described in problem 1 by the gains and in problem 2 by the losses. In this case, they found that individuals choice involving gains are often risk averse and choice involving losses are often risk taking. It indicates individuals' contradictory attitudes towards risks involving gains and losses.

Behavioural biases and prospects are abundant in an emerging financial market like India. A large amount of information, in a short period of time, forces individual investors to make decisions based on certain heuristics (Sahi, 2015). These heuristics enable individuals to make rapid but biased decisions. Along with these heuristics, individuals also exhibit certain sentiments and beliefs that encourage individuals to make biased decisions. Some examples of behavioural biases that we have considered in this study are overconfidence bias, disposition effect, herd behaviour, familiarity bias, loss aversion, self-attribution bias, 
anchoring bias, regret aversion, overreaction, mental accounting, hind sight bias, framing effect, representative bias and availability bias (Barber and Odean, 2000; Barberis and Thaler, 2003; Kahneman and Riepe, 1998; Kahneman and Tversky, 1979; Pompian, 2006; Shefrin and Statman, 1985; Tversky and Kahneman, 1974).

It is interesting to understand the decision-making behaviour of individual investors based on their beliefs and preferences. With this view, the objective of this study is to explore the various behavioural factors or biases that influence the investment decisions of individual investors in the Indian stock market. According to Crabtree and Miller (1992), a qualitative study is used to capture expressive information about values, beliefs, feelings and motivations that cause different behaviours. For the purpose of this exploratory study, an in-depth interview method was used because it provides much more exhaustive information and a relaxed atmosphere in which people feel more comfortable to provide information (Boyce and Neale, 2006).

The remainder of this paper is structured as follows: The first section briefly reviews the related literature. In the next section, we describe the research method and data analysis, followed by a section that presents the results and findings. The last section provides the conclusion and implication of this study.

\section{Related Literature}

Traditional finance is built on the notion of "homo economics", which states that humans always make perfectly rational choices to maximize their wealth and minimize risk (Pompian, 2012). That is, traditional finance has concern for how investors should behave rather than how actual investors are behaving (Baker and Nofsinger, 2002). An efficient market can be defined as a market wherein a large number of rational investors act to maximize profits in the direction of individual securities (Pompian, 2006). However, research studies on judgement and decision making have revealed that an individual's behaviour is inconsistent with rationality and Bayesian learning (Tourani-Rad and Kirkby, 2005). Thaler (1993) suggested that behavioural finance "entertains the possibility that some of the agents in the economy behave less than fully rationally some of the time" ( $p$. 17). Shefrin (2000) stated that investors are prone to committing errors of which some are negligible and others are fatal. Moreover, Archuleta et al. (2013) reported that financial practitioners have been facing clients who have financial problems that impact their cognitive, emotional, and relational well-being. Most individuals hold undiversified portfolios, trade actively, sell winning stocks while keeping loss-making stocks, and so on (Barber and Odean, 2011). Behaviour and biases of individual investors that differentiate them from rational actors or decision makers come under the purview of the micro-aspect of behavioural finance (Pompian, 2006). Micro-aspect of behavioural finance deals with the behavioural biases of the individual investors. 
Initially, Tversky and Kahneman (1974) have identified the presence of three heuristics (representativeness, availability and anchoring) in decision-making under uncertainty and risk.

These heuristics are shortcuts that are used to deal with new information. Although, De Bondt (2003) suggested that heuristics create the desired outcome, but on occasion, they lead to probable errors in judgements.

Kahneman and Rippie (1998) stated that people make judgements about the probabilities of the occurrence of an outcome and assign values to these outcomes. Consequently, these beliefs and values are considered together in the formation of preferences about options that are riskier. These judgements may have systematic errors known as biases (Tversky and Kahneman, 1974). Empirical evidence from psychological research suggests that individuals consider each decision to be unique. Kahneman and Lovallo (1993) explained that people generally engage in narrow framing and isolate their current decisions from their other decisions. Because of narrow framing, people ignore their portfolio and experience a relatively poor portfolio performance. Additionally, Kahneman (2003) stated that when people make decisions based on their intuition, they adopt the most readily available frame, which is narrow and entails suboptimal outcomes. Sahi et al. (2013) stated that to understand the behaviour of individuals' financial investment decisions, it is necessary to understand the various behavioural biases that influence their decision-making behaviour.

According to Pompain (2006), behavioural biases can be divided into two broad categories: cognitive deviation and emotional deviation. Both categories result in irrational choices and judgements. Cognitive deviations originate from faulty reasoning and logical errors and can often be corrected by providing better information and advice. On the contrary, emotional deviations are generated from intuitions. Therefore, they are difficult to rectify. Cognitive biases include anchoring and adjustment, availability bias, mental accounting, representativeness, ambiguity aversion and self-attribution bias. In contrast, emotional biases include endowment effect, loss aversion, status-quo bias and regret aversion. The major research studies on these biases are summarized in Table 1. 
Table 1. Summary of the literature on various behavioural biases

\begin{tabular}{|l|l|}
\hline Bias & Author (Year) \\
\hline Overconfidence & $\begin{array}{l}\text { Odean (1999), Daniel et al. (1998), Barber and Odean } \\
\text { (2000), } \\
\text { Gervais and Odean (2001) }\end{array}$ \\
\hline Herding & $\begin{array}{l}\text { Lakonishok et al. (1992), Scharfstein and Stein (1990), Christie } \\
\text { Huang (1995) }\end{array}$ \\
\hline Familiarity & French and Poterba (1991), Massa and Simonov (2006) \\
\hline Disposition effect & $\begin{array}{l}\text { Shefrin and Statman (1985), Odean (1998), Grinblatt and } \\
\text { Keloharju } \\
\text { (2001), }\end{array}$ \\
\hline Optimism & Toshino and Suto (2004), Shefrin and Statman (2011) \\
\hline Overreaction & Bondt and Thaler (1985) \\
\hline Mental accounting & Thaler (1999), Barberis and Huang (2001) \\
\hline Loss aversion & $\begin{array}{l}\text { Kahneman and Tversky (1979), Berkelaar and Kouwenberg } \\
\text { (2009), } \\
\text { Hwang and Satchell (2010) }\end{array}$ \\
\hline Status-quo bias & Samuelson and Zeckhauser (1988), Brown and Kagel (2009) \\
\hline Anchoring & Tversky and Kahneman (1974), Campbell and Sharpe (2009) \\
\hline Gambler's fallacy & Croson and Sundali (2005) \\
\hline
\end{tabular}

These biases can get reflected in the form of market anomalies such as economic crises (e.g., the dot-com bubble of the 1990's and the global financial crisis of 2007). These crises affected the stock market and were found to be very costly. Further, researchers found that poor financial decisions hurt productivity in the workplace also (Garman et al., 1996; Garman et al., 1999). Hence, it has become very important and vital to investigate investors' behaviour. This will be helpful in giving a deep insight to government and investment advisors into making policies, practices and more customized financial products that can fulfill the needs of individual investors. 


\section{Research Method}

The aim of this study is to explore the behavioural factors or biases that affect individuals' investment decision making. To understand the behaviour of individual investors in the Indian stock market, qualitative research was preferred. Qualitative research allows researchers to gain a better understanding of investors' behaviour by accessing their intentions, motives, beliefs, attitudes, rules and values that lie behind their decision making and make their actions and behaviour meaningful (Draper, 2004). Moreover, qualitative methods refer to various data collection techniques such as semi-structured open-ended interviews and observations (Choy, 2014; Draper, 2004). These qualitative methods are important in exploratory research, e.g., the use of open ended questions gives participants the opportunity to respond in their own words; provides more flexibility to researchers for probing the initial participant responses, like, to ask why or how (Mack et al., 2005). Qualitative research relies on textual data (i.e., data from audiotapes, videotapes and field notes) obtained from observations and interviews rather than on numerical data (by assigning numerical values to responses) of survey research (Draper, 2004). In this study, an exploratory, in-depth data collection is required to ascertain the importance of the concept noted above. For this purpose, face-to-face, in-depth semi-structured interviews were conducted to obtain the participants' views and opinions. The main advantage of using in-depth interviews is that they provide more detailed and thorough information than do the data obtained from the survey methods (Boyce and Neale, 2006).

\section{Sample}

In quantitative research studies, sampling is a crucial issue, and requires a representative sample to attain the objective of the study. But in the case of qualitative research, sample size tends to be small because researchers have to establish a fruitful relationship with the informants to address the research objective in depth (Crouch and McKenzie, 2006). Therefore, a few participants $(<20)$ can make easier the researcher's close relationship with the informants, and improve the validity of fine-grained, in-depth inquiry in qualitative research (Crouch and Mc Kenzie, 2006). In the qualitative study, the number of required subjects usually becomes obvious as the study progresses and adding more participants to the study does not result in additional perspectives or information (data saturation) (Glaser and Strauss,1967; Marshall, 1996). Research has shown this usually occurs once 10-18 participants have been interviewed (Korb, 2010).

Random sampling or probability sampling is very common and likely to be accurate because all members have an equal chance of being selected. However, in the case of qualitative study, random sampling is not appropriate. This is because in random sampling, characteristics of the whole population should be known, which is not possible in a complex qualitative study (Marshall, 1996). Additionally, random sampling creates representative 
sample only if the research characteristics (e.g. value, attitudes and beliefs etc.) are randomly distributed within the population. Although, there is no evidence that above mentioned characteristics are randomly distributed (Marshall, 1996). Therefore, purposive sampling was used to select participants. This is for the reason that purposive sampling assists in identifying and selecting individuals that are knowledgeable about and experienced with a phenomenon of interest (Cresswell and Plano Clark 2011). For this study, target participants were investment advisors, analysts and brokers having a minimum of 5 years of experience in various popular securities firms in India (see Table 2). Agarwalla et al. (2012) have attempted to examine the level of financial literacy in India and report a poor level of financial literacy. Moreover, individuals are mostly dependent on financial advisors for their investments. Thus, because of poor financial literacy individual investors could be more biased in providing information; therefore, investment advisors were chosen to provide more detailed and thorough information about the behaviour of individuals investing in the Indian stock market. Advisors of different securities firms deal with their clients (i.e., individual investors) and focus on their clients' investment goals, needs and reaction to losses. Nowadays, advisors are becoming increasingly aware that individuals' personality traits, demographic and socio-economic factors, cognitive and emotional biases affect their financial and investment- related decisions (Baker and Ricciardi, 2015). To facilitate the identification of investment advisors, a snowball method was used. In the snowball method, one subject gives the researcher the name of another subject, who in turn provides the name of a third, and so on (Vogt, 1999). In keeping with the qualitative approach to the study, interviews were carried out until similar and repetitive responses were gathered on the subject matter, and new data could no longer bring any additional insights into the research objectives (Korb, 2010; Mack et al., 2005). In this study, new themes stopped emerging after about 13-15 interviews and an acceptable interpretative framework was constructed after 20 interviews.

Table 2. Respondent Profile

\begin{tabular}{llll}
\hline S. No. & Designation & Gender & Experience \\
\hline 1. & Deputy Manager- Treasury and Equity Male & $5 / 10$ years \\
2. & Senior Manager & Male & $10 / 15$ years \\
3. & Wealth Manager & Male & $5 / 10$ years \\
4. & Assistant Vice President & Male & $10 / 15$ years \\
5. & Assistant Manager & Male & $5 / 10$ years
\end{tabular}



6. Owner
Male
$10 / 15$ years
7. Assistant Manager
Male
$5 / 10$ years
8. Wealth Manager
Male
$15 / 20$ years
9. Investment Manager
Female
$5 / 10$ years
10. Deputy Manager
Male
$5 / 10$ years
11. Fund Manager
Male
$5 / 10$ years
12. Owner
Male
$10 / 15$ years
13. Fund Manager
Male
$5 / 10$ years
14. Owner
Male
$>20$ years
15. Investment Manger
Male
$5 / 10$ years
16. Wealth Manager
Male
$5 / 10$ years
17. Owner
Male
$15 / 20$ years
18. Assistant Manager
Male
$5 / 10$ years
19. Senior Manager
Male
$>20$ years
20. Owner
Male
$10 / 15$ years

Therefore, 20 face-to-face in-depth semi-structured interviews were conducted to explore the behavioural factors of individuals that affect investment decisions. Each interview lasted for 30 minutes to 1 hour. The data were recorded through an audiotape recorder, with the prior permission of informants. The interviews were carried out at the informants' offices by taking prior appointments.

In this study, to obtain informants' viewpoints in their own words, interview guidelines with open-ended questions were followed (Kavle, 1996, 2007; Paetzold and Busch, 2014). Initially, in the interview, the interviewer asked the informants as to what factors individuals consider when investing in securities. Further, the interview was continued and respondents were asked some prepared questions, and follow-up questions were based on the answers given to the initial question. By following this approach, the interviewer could obtain detailed information from the informants. 


\section{Data Analysis}

The data for this study were obtained from interview transcripts recorded through an audiotape recorder during the interviews. Further, notes were written down by listening to the recording of these interview transcripts. These notes helped to reconstruct the original comments, observations and feelings (Schutt, 2014). "The basic data are these observations and conversations, the actual words of people reproduced to the best of my ability from the field notes" (Diamond, 1992, p. 7). In this study, thematic content analysis was used to analyse interview transcripts. According to Burnard et al. (2008) and Boyatzis (1998), the thematic content analysis process involves analysis of transcripts, coding and identification of themes from data. Hence, all the information collected from the informants was thoroughly reviewed and notes were made in the form of summary statements or short phrases. This is known as coding to uncover themes. These transcripts were categorized into different codes namely, volatility, risk factor, safe playing, avoid losses, greed and risk averse, overconfident, effect of rumours and investment in familiar assets etc. The main motive is to develop a coding system that it will enable the conversion of data into meaningful and specific units of information. All the phrases and statements noted were later analysed, and duplicate phrases (which gave the same meaning) were eliminated. From these codes, appropriate themes with strong arguments supported by many informants were identified as major biases that affect investors' investment decision making.

\section{Results and Findings}

In Table 1, different behavioural biases have been identified from the previous research studies. However, the analysis of the interviews highlighted certain different themes also that individuals' exhibit while making their investment decisions. The findings are presented using the traditional approach. In the traditional approach, key findings are reported under each theme and then accompanied by linking a separate discussion in which findings are discussed in relation to our study (Burnard et al., 2008). Here, the key findings under each theme were reported by using suitable opinions of the informants.

\section{Past market returns and volatility}

People make investment decisions based on the historical returns and volatility in the stock market. This revealed that people in the stock market get intimidated by volatility. In the Indian equity market, the majority of the people invest with the desire of obtaining shortterm benefits. Thus, there are more speculators than investors. Sometimes, because of these speculators, volatility increases because their decisions are generally based on rumours. This is evident from the following opinions of the informants: 
"From the 2008 crisis and volatility in the market, we can see that...people moved away from the market".

"Investors overreact when market volatility is high and they lose money". "In volatile situations, they panic and tend to trade excessively".

\section{Preference for safe returns}

Research studies indicate that people lack the financial literacy necessary to make important financial decisions (Mandell and Klein, 2009). People are rather unaware of the various financial products available. They prefer to invest their money in traditional investment products, such as fixed deposits and public provident funds, where they can get safe returns. However, their investment plans can be based on three broad parameters in order of preference- returns, liquidity and safety. This is substantiated by the following: "Investors invest their hard earned money in safe assets such as fixed assets, real estate and gold".

"Equity is a very good asset class for the long term investment, but people lack patience and lose money".

\section{Tendency to believe they are better than others}

Previous studies have identified that people tend to exhibit the overconfidence phenomenon while they invest (Baker and Nofsinger, 2002). In our study, informants stated that most of the people are overconfident about their abilities to make better decisions than others. Although they do not know the right time to enter or exit from the market, they tend to make decisions based on others. Baker and Nofsinger (2002) stated that people have the illusion of knowledge and the illusion of control. This is evidenced by the following statements:

"Everyone believes that what they are doing or thinking is correct and trade excessively". "Investors initially listen to advisors after which they start choosing stocks on their own". "People believe that they are better than others while choosing stocks".

"At the time of buying and selling the stocks, they are confident that they are right". "Investors go by their own choice and prefer not to listen to advisors".

\section{Tendency to hold on to loss-making assets}

People have the tendency to hold on to loss-making stocks and sell profit-making stocks. Our interviews revealed that investors never sell their stocks on loss because they do not 
want to book losses. They think that their share will attain the actual purchase price. This effect is risky to the clients because it can increase the capital gains taxes that individuals incur and can reduce returns even before taxes (Baker and Ricciardi, 2015). If the share price is -INR 1 higher than the purchase price, (i.e., profit) then investors sell that share. However, if prices go below INR 10, (i.e., loss) investors will not sell stocks but will prefer to wait, as is seen by the following statements:

"It is very difficult for retail investors to book losses. They only book intended losses". "When they entered the market during the loss-making situation, they never sell and get affected by emotions".

"In the case of a loss, few people sell their stocks because they lose patience". "Longterm investors never book losses. They always see the profit". "Generally, clients book profits and wait for the loss".

\section{Preference to invest in familiar securities}

Some people prefer to invest in a particular asset class or in a particular sector because they are familiar with it. In the case of the equity market (i.e., if someone is working in the banking sector), he/she may or may not invest a major part in that particular sector. This is because people have more knowledge and experience of such investment products and feel secure and comfortable as is seen below:

"They prefer to invest in those shares that are in the news and with which they are familiar". "Only a few investors invest in familiar investments".

\section{Tendency to have regret for making past decisions}

Some people tend to avoid making certain investment decisions because they feel regretful. Baker and Nofsinger (2002) stated that large losses cause the investor emotional pain. This is the reason that there are likely chances to less participation of retail investors in the Indian equity market. If people have experienced losses earlier on any particular stocks, then they would avoid making an investment in those stocks as seen below:

"After losing patience, they never come back to invest in the equity market". "Regret causes a loss of their risk appetite".

"Again individual investors will not enter the market with a large amount".

"Because of a previous loss, they are fearful and do not want to come back to the equity market". "Some people will want to reinvest in the equity market, but only after a period of time". 
"They may switch over to other shares or sectors".

"After a loss, people sometimes tend to stay away not only from that particular share but also from the share market". Tendency to have more sensitivity towards losses than gains

People tend to be more disheartened and unhappy in the case of losses. People give more weight to losses rather than giving importance to the same amount of gain.

Therefore, they try to avoid losses and keep them in their portfolio as seen below:

"They try to minimize losses by holding on to loss making assets".

"People tend to feel more pain towards their loss than pleasure on the same amount of gain". "They book profits earlier than losses and become sensitive to loss".

"When they have a loss, they tend to think they will recover the amount lost, and it is with this tendency that they book more loss".

\section{Tendency to invest by looking at the framing of the outcome}

In the case of a gain, people tend to prefer a certain gain. If the same problem is presented in different frames, one is positive and the other is negative. People tend to assign values to individual outcomes rather than focusing on aggregate returns. In the situation of a gain, people may invest in a company that has a certain gain (i.e., positive frame), but in the situation of a possible loss, people are ready to take more risks (i.e., negative frame). However, both these statements have the same outcome as seen below:

"In the situation of guaranteed gain, investors do not take any risk. They want safe returns". "They want certainty in the case of gains but never take certainty in the case of a loss". "People tend to take risks in the situation of a loss".

\section{Tendency to buy rising stocks with the expectation that this rise will continue}

Interviews revealed that people have a tendency to buy rising stocks that are already overvalued. Redhead (2008) suggested that people have a tendency to buy when the market has risen and to sell when the market falls. However, rises of the market are related to its own previous rises and due to cash inflows that shows momentum effect. People then hold these stocks and expect that this rise will continue in the future as is stated below:

"When the stock is overvalued, they keep holding that stock and wait till its value increases". "Clients do not do their homework related to previous stock prices and market trends." 


\section{Follows the past trend of stocks}

Some people make their investment decisions based on the past performance of a particular share. People believe that if any stock has had a good performance, this will happen again in the future. However, individuals lack knowledge of the fundamentals and technical aspects of stocks. In the Indian stock market, there are two types of investors: bullish and bearish. The former consider that if the market had exhibited a rising trend earlier, it will also continue to rise in the future; however, the latter have the opposite view:

"People believe that the past trends of stocks will continue in the future also". "People follow the past trend before investment".

"People buy shares that have recently increased in price".

\section{Tendency to rely on other sources of information}

Interviews revealed that people tend to rely on others including friends, family members and relatives. People trust the judgement of others and follow the decisions of the crowd. They also follow the news and media without looking at the fundamentals of the company, as is stated below:

"They have other sources of information including media, friends and relatives". "In this market, more than $50 \%$ of people invest by listening to others".

"They believe rumours and follow others".

"The media plays a major role in influencing investment decision making of individuals".

\section{Tendency to rely on the reference point}

People tend to rely on a set of information or a value that is known as a reference point to make any investment decision. These values are known as the reference point, which is considered as the basis for making investment decisions in the future. Interviews revealed that people rely on the "purchase price", " 52 -week high price" and "rate of return" as a point of reference. People have a sense of satisfaction by considering the reference point as a benchmark to judge their investment decisions, as is seen below:

"Investors set their reference point, and generally, it is the purchase price of the share". "Individuals plan to sell only if the share price goes above the initial purchase price". "People avoid sale stocks that have gone below the purchase price". 


\section{Tendency to invest based on information easily available}

People have a tendency to jump to conclusions based on information easily available. They feel that the information that they have is very important for decisions to be made. People remember an event or incident that happened in the stock market based on which they make future investment decisions. When decisions are made based on easily available information, people feel strongly satisfied that they have made decisions based on information, as is understood from the following:

"People have a very short-term memory. They look at the very recent event and behave accordingly".

"Suppose it is highlighted in the news that share prices of Company $\mathrm{X}$ are expected to increase, people will buy these shares".

"Sometimes, investors react to easily available news; in fact, sometimes, they even overreact".

\section{Tendency to rely on own skills}

Some people rely on their own experience and skills while making investment decisions. They feel that they have more knowledge than advisors do and can make realistic decisions for themselves. Therefore, people tend to believe that their intuitions are correct and perhaps they do not believe others regarding decisions for their money:

"Some people do not listen to advisors and believe their own experience before making investment decisions".

"After a certain point of time, they feel that have more knowledge than advisors do".

\section{Tendency to divide their money into different accounts/assets}

Interviews revealed that people tend to divide their money into separate accounts based on their specific needs. People tend to make categories mentally, such as money for retirement funds and child plans, and allocate their money to these categories. People also do these kinds of accounting to evaluate the performance of their shares. Few people evaluate the overall stock market holding and feel happy or upset based on gains or losses, respectively. However, most of the investors evaluate the value of individual stocks that they own as seen below:

"They segregate their money into different assets, etc.".

"They are not systematic. They do not stick to such kind of things".

"People value individual stocks and feel upset if they possess loss making stocks". 


\section{Tendency to believe that past events were predictable}

Interviews revealed that people have a tendency to feel what had happened in the past was already predicted (when analysed in the future). They felt that they already knew what would happen, as is stated below:

"Some people reacted as if they were already informed and felt that the listener did not pay attention to them at that time".

"They felt that they had an intuition that prices of this share were going to rise".

\section{Conclusion and Implications}

This study investigated the psychological biases of individual investors as observed and interpreted by their financial advisors and brokers that affect their investment decisions in the Indian stock market. To achieve this objective, a qualitative method based on in-depth interviews was used. Twenty investment advisors having a minimum 5 years' experience in securities firms were interviewed. These advisors expressed their beliefs and observations relating to the behaviour of their clients investing in the stock market. From the previous section, it can be observed that individuals exhibit various beliefs and psychological biases in their behaviour while investing in the Indian stock market. The findings of the interviews revealed 13 biases based on certain themes. These biases have a negative connotation because they produce a distortion in the calculation of an outcome.

These biases are classified under three categories. Table 3 presents the categorization of individual investors' behavioural biases.

Cognitive errors: People have patterns of thinking that may affect their behaviour. Cognitive errors originate because of faulty reasoning, statistical errors, lack of information, memory errors and logic. When a decision-making process is cognitively biased, the outcome leads to sub- optimal results or judgmental errors.

Emotional biases: Emotional errors are developed from impulse and intuitions rather than from conscious calculations. Emotionally biased decisions denote that they have been influenced by feelings, moods and emotions. This leads to irrational decisions or actions (Pompian, 2006). 
Table 3. Categorization of individual investor's behavioural biases

\begin{tabular}{|c|c|c|c|}
\hline & & Overconfidence bias & Tendency to believe they are better than others \\
\hline & & Disposition Effect & Tendency to hold loss making assets \\
\hline & & Familiarity bias & Prefer to invest in familiar securities \\
\hline & & Framing effect & $\begin{array}{l}\text { Tendency to make investment by looking at the framing } \\
\text { of } \\
\text { the outcome }\end{array}$ \\
\hline & & Anchoring bias & Tendency to rely on reference point \\
\hline 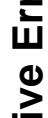 & & Availability bias & $\begin{array}{l}\text { Tendency to invest based on information easily } \\
\text { available }\end{array}$ \\
\hline & & Self-Attribution bias & Rely on their own skills \\
\hline & & Representativeness & $\begin{array}{l}\text { Tendency to buy rising stocks with the expectation that } \\
\text { this rise will continue. } \\
\text { Follows past trend of stocks }\end{array}$ \\
\hline & & Mental Accounting & $\begin{array}{l}\text { Tendency to divide their money in to different accounts/ } \\
\text { assets }\end{array}$ \\
\hline & & Hindsight bias & Tendency to believe that past events were predictable \\
\hline & & Regret Aversion & Tendency to feel regret for past decisions \\
\hline 을 & 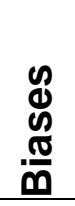 & Loss Aversion & $\begin{array}{l}\text { Tendency to have more sensitivity towards losses than } \\
\text { gains }\end{array}$ \\
\hline $\begin{array}{l}\bar{\pi} \\
0 \\
\text { ஸ }\end{array}$ & 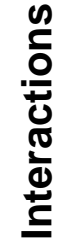 & Herding $\quad$ bias/Medi & Tendency to rely on other sources of information \\
\hline
\end{tabular}


Social interaction: Like other social animals, people tend to follow the behaviours and attitudes of the majority to feel safe and avoid conflict. If the majority starts to move in one direction, the others will also automatically follow. The biases of social interaction contribute to bubbles and market anomalies such as the tech bubble of 1999-2000 and the housing crisis. These bubbles went to extreme levels when people rushed into the markets and invested their money.

The findings of this study may assist both financial service providers and researchers to understand the various psychological biases of individual investors in investment decision making. Additionally, individual investors will also be aware of the behavioural biases that will aid them to make sensible and efficient investment decisions. Understanding of these behavioural finance issues applied to investor behaviour can provide financial planners and advisers with additional knowledge to help their clients in making better judgments that potentially lead them to improve investment results. This will help investors to achieve greater financial well-being. One limitation of the qualitative research is that the sample used by the researchers cannot be generalized to the whole population. Although flexible sampling approaches of qualitative research helps in examining the issues in more detail and in depth. Moreover, one limitation that is specific to this study is that major biases have been identified from this study; there could be more behavioural biases that can influence individual investors' investment decisions. Therefore, in the future, it will be interesting to explore other biases prevalent in various countries. This will provide financial regulators and financial service providers with a deep insight into the behaviour of individual investors. In addition, to support the findings of the present study, a quantitative study can be conducted on a large number of individual investors investing in the Indian stock market. This may help in confirming the presence and influence of these psychological biases on individual investors' investment decisions in Indian stock market.

\section{References}

Agarwalla, S. K., Barua, S., Jacob, J. and Varma, J. R. (2012) 'A survey of financial literacy among students, young employees and the retired in India', Available at http://www.iimahd.ernet.in/fls/fls12/youngemployessandretired2012.pdf_(assessed July 2014)

Archuleta, K. L., Dale, A. and Spann, S. M. (2013) 'College students and financial distress: Exploring debt, financial satisfaction, and financial anxiety', Journal of Financial Counseling and Planning, Vol. 24 No. 2, pp.50-62.

Baker, H. K. and Nofsinger, J. R. (2002) 'Psychological biases of investors', Financial Services Review, Vol. 11 No. 2, pp.97-116.

Baker, H. K. and Ricciardi, V. (2015) 'Understanding behavioral aspects of financial planning and investing', Journal of Financial Planning, Vol. 28 No. 3, pp.22-26. 
Barber, B. M. and Odean, T. (2000) 'Trading is hazardous to your wealth: The common stock investment performance of individual investors', The Journal of Finance, Vol. 55 No. 2, pp.773-806.

Barber, B. M. and Odean, T. (2011) 'The behavior of individual investors', Available at SSRN: https://ssrn.com/abstract=1872211. doi:http://dx.doi.org/10.2139/ssrn.1872211

Barberis, N. and Huang, M. (2001) 'Mental accounting, loss aversion, and individual stock returns', The Journal of Finance, Vol. 56 No. 4, pp.1247-1292.

Barberis, N. and Thaler, R. (2003) 'A survey of behavioral finance' In G. M. Constantinides, M. Harris \& R. M. Stulz (Eds.), Handbook of the economics of finance: Financial markets and asset pricing, Elsevier, pp.1053-1128.

Berkelaar, A. and Kouwenberg, R. (2009) 'From boom 'til bust: How loss aversion affects asset prices', Journal of Banking \& Finance, Vol. 33 No. 6, pp.1005-1013.

Bondt, W. F. and Thaler, R. (1985) 'Does the stock market overreact?', The Journal of Finance, Vol. 40 No. 3, pp.793-805.

Boyatzis, R. E. (1998) 'Transforming qualitative information: Thematic analysis and code development', Sage, Thousand Oaks, CA.

Boyce, C. and Neale, P. (2006) 'Conducting in-depth interviews: A guide for designing and conducting indepth interviews for evaluation input', Pathfinder International, Watertown, MA

Brown, A. L. and Kagel, J. H. (2009) 'Behavior in a simplified stock market: The status quo bias, the disposition effect and the ostrich effect', Annals of Finance, Vol. 5 No. 1, pp.1- 14.

Burnard, P., Gill, P., Stewart, K., Treasure, E. and Chadwick, B. (2008) 'Analysing and presenting qualitative data', British Dental Journal, Vol. 204 No. 8, pp.429-432.

Campbell, S. D. and Sharpe, S. A. (2009) 'Anchoring bias in consensus forecasts and its effect on market prices', Journal of Financial and Quantitative Analysis, Vol. 44 No. 2, pp. 369-390.

Choy, L. T. (2014) 'The strengths and weaknesses of research methodology: Comparison and complimentary between qualitative and quantitative approaches', IOSR Journal of Humanities and Social Science, Vol. 19 No. 4, pp.99-104.

Christie, W. G. and Huang, R. D. (1995) 'Following the pied piper: Do individual returns herd around the market?', Financial Analysts Journal, Vol. 51 No. 4, pp.31-37.

Crabtree, B. F. and Miller, W. L. (1992) 'Doing qualitative research,'Sage.

Creswell, J. W. and Plano Clark, V. L. (2011) 'Designing and conducting mixed method research', Sage, Thousand Oaks, CA.

Croson, R. and Sundali, J. (2005) 'The gambler's fallacy and the hot hand: Empirical data from casinos', Journal of Risk and Uncertainty, Vol. 30 No. 3, pp.195-209. 
Crouch, M. and McKenzie, H. (2006) 'The logic of small samples in interview-based qualitative research', Social Science Information, Vol. 45 No. 4, pp.483-499.

Daniel, K., Hirshleifer, D. and Subrahmanyam, A. (1998) 'Investor psychology and security market underand overreactions', The Journal of Finance, Vol. 53 No. 6, pp.1839-1885.

De Bondt, W. F. M. (2003) 'Bubble psychology', In W. C. Hunter, G. C. Kaufman \& M. Pomerleano (Eds.), Asset price bubbles: The implications for monetary regulatory and international policies, The MIT Press, pp.205-216.

Diamond, T. (1992) 'Making gray gold: Narratives of nursing home care', University of Chicago Press, Chicago, IL.

Draper, A. K. (2004) 'The principles and application of qualitative research', Proceedings of the Nutrition Society, Vol. 63 No. 4, pp.641-646.

Fama, E. F. (1970) 'Efficient capital markets: A review of theory and empirical work', The Journal of Finance, Vol. 25 No. 2, pp.383-417.

French, K. R. and Poterba, J. M. (1991) 'Investor diversification and international equity markets', The American Economic Review, Vol. 81 No. 2, pp.222-226.

Garman, E. T., Kim, J., Kratzer. C. Y. and Brunson, R. H. (1999) 'Workplace financial education improves personal financial wellness', Journal of Financial Counseling and Planning, Vol. 10 No. 1, pp.79-88.

Garman, E. T., Leech, I. E. and Grable, J. E. (1996) 'The negative impact of employee poor personal financial behaviors on employers', Journal of Financial Counseling and Planning, Vol. 7, pp. 157-168.

Gervais, S. and Odean, T. (2001) 'Learning to be overconfident', Review of Financial Studies, Vol. 14 No. 1, pp.1-27.

Glaser, B. G. and Strauss, A. L. (1967) 'The discovery of grounded theory: Strategies for qualitative research', Transaction, Piscataway, New Jersey.

Grinblatt, M. and Keloharju, M. (2001) 'How distance, language, and culture influence stockholdings and trades', The Journal of Finance, Vol. 56 No. 3, pp.1053-1073.

Hwang, S. and Satchell, S. E. (2010) 'How loss averse are investors in financial markets?', Journal of Banking \& Finance, Vol. 34 No. 10, pp.2425-2438.

Kahneman, D. (2003) 'A perspective on judgment and choice: mapping bounded rationality', American Psychologist, Vol. 58 No. 9, pp.697-720.

Kahneman, D. and Lovallo, D. (1993) 'Timid choices and bold forecasts: A cognitive perspective on risk taking', Management Science, Vol. 39 No. 1, pp.17-31.

Kahneman, D. and Riepe, M. W. (1998) 'Aspects of investor psychology', The Journal of Portfolio Management, Vol. 24 No. 4, pp.52-65. 
Kahneman, D. and Tversky, A. (1979) 'Prospect theory: An analysis of decision under risk', Econometrica: Journal of the Econometric Society, Vol. 47 No. 2, pp.263-291.

Korb, B. (2010) 'Financial planners and baby boomer widows: Building a trusting relationship', Journal of Financial Planning, Vol. 23 No. 1, pp.48-53.

Kvale, S. (1996) 'Interviews: An introduction to qualitative research interviewing', Sage, Thousand Oaks, CA.

Kvale, S. (2007) 'Doing interviews', Sage, London.

Lakonishok, J., Shleifer, A. and Vishny, R. W. (1992) 'The impact of institutional trading on stock prices', Journal of Financial Economics, Vol. 32 No. 1, pp.23-43.

Mack, N., Woodsong, C., MacQueen, K., Guest, G. and Namey, E. (2005) 'Qualitative Research Methods: A Data Collector's Field Guide', Research Triangle Park, NC, USA: Family Health International.

Mandell, L. and Klein, L. S. (2009) 'The impact of financial literacy education on subsequent financial behavior', Journal of Financial Counseling and Planning, Vol. 20 No. 1, pp.15- 24.

Marshall, M. N. (1996) ‘Sampling for qualitative research’, Family Practice, Vol. 13 No. 6, pp.522-526.

Massa, M. and Simonov, A. (2006) 'Hedging, familiarity and portfolio choice', Review of Financial Studies, Vol. 19 No. 2, pp.633-685.

Odean, T. (1998) 'Are investors reluctant to realize their losses?', The Journal of Finance, Vol. 53 No. 5, pp.1775-1798.

Odean, T. (1999) ‘Do Investors Trade too Much?', The American Economic Review, Vol. 89 No. 5, pp.1279-1299.

Paetzold, F. and Busch, T. (2014) 'Unleashing the Powerful Few Sustainable Investing Behaviour of Wealthy Private Investors; Organization \& Environment, Vol. 27 No. 4, pp.347-367.

Pompian, M. M. (2006) 'Behavioral Finance and Wealth Management: How to Build Optimal Portfolios for investor biases', John Wiley \& Sons, Inc. Hoboken, New Jersey.

Pompian, M. M. (2012) 'Behavioral Finance and Investor Types: Managing Behavior to Make Better Investment Decisions', John Wiley \& Sons, Inc. Hoboken, New Jersey.

Redhead, K. (2008), Personal finance and investments: a behavioural finance perspective', Routledge.

Sahi, S. K. (2015) 'Investor Biases in Financial Decisions', In Z. Copur (Eds.), Handbook of Research on Behavioral Finance and Investment Strategies: Decision Making in the Financial Industry, pp.147-169.

Sahi, S. K., Arora, A. P. and Dhameja, N. (2013) 'An exploratory inquiry into the psychological biases in financial investment behavior', Journal of Behavioral Finance, Vol. 14 No. 2, pp.94-103.

Samuelson, W. and Zeckhauser, R. (1988) 'Status quo bias in decision making', Journal of Risk and Uncertainty, Vol. 1 No. 1, pp.7-59. 
Scharfstein, D. S. and Stein, J. C. (1990) 'Herd behavior and investment', The American Economic Review, Vol. 80 No. 3, pp.465-479.

Schutt, R. K. (2014) 'Investigating the social world', Sage Publications.

Shefrin, H. (2000) 'Beyond greed and fear: Understanding behavioral finance and the psychology of investing', Oxford University Press.

Shefrin, H. and Statman, M. (1985) 'The disposition to sell winners too early and ride losers too long: Theory and evidence', The Journal of Finance, Vol. 40 No. 3, pp.777-790.

Shefrin, H. and Statman, M. (2011) 'Behavioral finance in the financial crisis: Market efficiency, Minsky, and Keynes', Santa Clara University.

Thaler, R. H. (1993) 'Advances in Behavioral Finance', Russell Sage Foundation, New York. Thaler, R. H. (1999) 'Mental accounting matters', Journal of Behavioral Decision Making, Vol. 12 No. 3, pp.183206.

Toshino, M. and Suto, M. (2004) 'Cognitive biases of Japanese institutional investors: Consistency with behavioral finance', Waseda University Institute of Finance Working Paper Series WIF-04-005.

Tourani-Rad, A. and Kirkby, S. (2005) 'Investigation of investors' overconfidence, familiarity and socialization', Accounting \& Finance, Vol. 45 No. 2, pp.283-300.

Tversky, A. and Kahneman, D. (1974) 'Judgment under uncertainty: Heuristics and biases', Science, Vol. 185 No. 4157, pp.1124-1131.

Tversky, A. and Kahneman, D. (1981) 'The framing of decisions and the psychology of choice', Science, Vol. 211 No. 4481, pp.453-458.

Vogt, W. P. (1999) 'Dictionary of Statistics and Methodology: A Nontechnical Guide for the Social Sciences', Sage, London. 